\title{
The New Bank-Thrift Competition: Will It Affect Bank Acquisition and Merger Analysis?
}

\author{
MICHAEL E. TREBING
}

$\mathrm{T}_{\mathrm{HF}}$

Depository Institutions Deregulation and Monetary Control Act (MCA) enacted by Congress in March 1980 will significantly affect the competitive environment in which financial institutions operate. This act broadens both the asset and liability powers of savings and loan associations ( $\& \& L s$ ), mutual savings banks and credit unions, opening opportunities for these institutions that traditionally have been limited to banks. In light of these new powers and the increasing erosion of both legal and economic differences between thrift institutions and banking organizations, thrifts have become important competitors in markets for banking services - especially for transaction or checking accounts. ${ }^{1}$ Logically, the presence of thrift institutions should carry greater weight in analysis of mergers between commercial banks and acquisitions of banks by bank holding companies (BHCs).

The following discussion reviews several provisions of the MCA that permit more intense bank-thrift competition, describes the current approach used by banking regulatory agencies to review applications for approval of bank mergers and BHC acquisitions, and discusses its validity in light of the new legislation. Finally, the article discusses some alternative approaches to the analysis of competition in local markets.

\section{THE MCA PROVISTONS}

The distinctions between thrifts and banks have become less rigid because of a long list of recent finan-

"The term "thrift institutions" in this article is defined as savings and loan associations, credit unions and nutual savings banks. cial innovations and the geographic expansion of socalled "non-banking" institutions." The MCA, in response to these developments, reduces even further the actual differences between banks and thrifts. Regulations that have attempted to control or constrain pricing and portfolio decisions of financial institutions are being liberalized. In essence, the act provides for a greater reliance on market forces to determine both the flow of deposits to financial institutions and the flow of credit from these institutions to borrowers. The major elements of the MCA that will affect bankthrift competition are listed in table $1 .^{3}$

An important change is the authorization of interestearning "transaction" accounts at both banks and thrifts. This is achieved through the nationwide legalization of negotiable order of withdrawal (NOW) accounts, automatic transfer service (ATS) accounts and credit union share drafts. ${ }^{4}$ In some areas of the country (especially New England), depository in-

"See Jean M. Lovati, "The Growing Similarity Among Financial Institutions," this Review (October 1977), pp. 2-11, and Harold C. Nathan, "Nonbank Organizations and the McFadden Act," Journal of Bank Research (Summer 1980), pp. $80-86$.

3For a more detailed discussion of the elements of the MCA see "The Depository Institutions Deregulation and Monetary Control Act of 1980," Federal Reserve Bulletin (June 1980), pp. 444-53.

${ }^{4} \mathrm{ATS}$ and NOW accounts represent a type of individual "checking" account. By providing for the attomatic transfer of funds from a savings account to cover checks drawn against a zerom balance ATS account individuals can earn interest on "checking" balances. NOW accounts are interest-eaming savings accounts against which customers car write "negotiables drafts." Similarly, credit union share drafts permit payable drafts drawn on a credit union member's interest-earning share account. Share drafts, which resemble checks, are processed through the credit union's account at a commercial bank. 
Table 1

\section{Selected Provisions from the Depository Institutions Deregulation and Monetary Control Act of 1980}

1. The phase-out of interest late cellings on deposits ovet a six year period

2 The authorization to offer NOW (hegotiable order of withdrawal) accounts (fundamentally, interesteaming checking accounts) at al federally insuled depository institutions beginning December 31, 1980 to individuals and non-profli organzations

3. The authortzation of share dratis at federally insured credit unions (effect ve March 31, 1980)

4. The authorization lor nutual savings banks lo offe demand deposits to business customers

5 Increased itvestment optlons for thrift Institutions

For tederal chartered savings and loans:

as consumer lending commorclal papor and debt securty investment of up 1020 per cent of assets

b. issuance of credit cards:

c. trust-fiduclary powers

For tederally insured credit unions:

a. real estate loans

For federal mutual savings banks:

a commercial, corporate and business loans (up to 5 percent of assets

stitutions had already offered interest-earning transaction accounts since the early 1970s. Accompanying these powers is the provision for the gradual phaseout of deposit interest rate ceilings.

In addition to these significant changes, the MCA allows S\&Ls to engage in consumer lending, trust activities and credit card operations. The MCA authorizes thrifts to invest in, sell, or hold commercial paper and corporate debt securities (up to 20 percent of assets). Limited business and commercial loan powers have also been granted to federally chartered mutual savings banks.

The basic findings of the act are that the existing institutional structure has discouraged persons from saving, created inequities for depositors, impeded the ability of depository institutions to compete for funds and failed to achieve an even flow of funds among institutions. The act also states that all depositors are entitled to receive a market rate of return on their savings.
Credit market activity of thrifts over the past decade has developed by piecemeal expansion; these institutions evolved originally as special-purpose institutions whose asset-liability powers have been extended only by gaining legislative approval. ${ }^{5}$ Legislation in the $1970 \mathrm{~s}$ has increasingly widened their powers and scope of business. The new powers legalized in the MCA will affect further the traditional lines of business that have separated these institutions; banks and thrifts will now compete more directly for many lines of business.

\section{CURRENT METHOD OF ANALYZING COMPETITION}

The Bank Holding Company Act of 1956 requires the Federal Reserve to consider the likely effects of proposed holding company formations and acquisitions on competition, the convenience and needs of the communities involved, and the financial and managerial resources and future prospects of the institutions involved. ${ }^{6}$ If the Board of Governors finds that a transaction will substantially lessen competition (or tend to create a monopoly or be in restraint of trade), the Board must deny the application unless the anticompetitive effects are judged to be clearly outweighed by "the convenience and needs of the community."

\section{Legal Doctrine}

The critical problem in antitrust law is selecting the specific industry and industry output (or "line of commerce") to use in analyzing competition between firms. In analyzing cases under the Bank Holding Company Act, the Federal Reserve has generally chosen "commercial banking" to be the relevant line of commerce. This definition is based on the Supreme Court's controversial Philadelphia National Bank decision in $1963 .{ }^{7}$

In this case, the Court concluded that commercial banks have an advantage over other financial institutions in attracting funds for loans and other services

5See Leonard Lapidus, "Commercial Banks and Thrift Institutions: The Differing Portfolio Powers," Banking Law Joumal (May 1975), pp. 450-93, and Jean M. Lovati, "The Changing Competition Between Commercial Banks and Thrift Instithtions for Deposits," this Review (July 1975), pp. 2-8.

-Competitive analysis is also done with respect to applications filed zunder: the Change in Bank Control Act of 1978 and mergers filed under the Bank Merger Act of 1960

Ttnited States v. Philadelphia National Bank, 374 U.S. 321 (1963). Subsequent Supreme Court cases have upheld this decision. See United States v. Phillipsburg National Bank and Trust Co., 399 U.S. 350 (1970); and United States v. Connecticut National Bank, 418 U.S. 655 (1974). 
since only they can legally accept demand deposits. In addition, banks were said to enjoy "settled consumer preferences" for full-service banking. Thus, the "general store" nature of the banking business made it a distinct line of commerce, distinguishing banks from other financial institutions.

Banking agencies have relied on simple market share tests to judge the likely effects of mergers or BHC acquisitions on competition, using "concentration ratios" as a form of prima facie evidence of these effects on competition. A concentration ratio is a summary measure intended to represent the degree of market power that larger firms possess. ${ }^{8}$ This ratio is defined as the percentage of total industry activity (measured by output, employment, assets, etc.) accounted for by the larger firms. A four-firm concentration ratio (using total deposits as a proxy for output) for all the commercial banks in a local banking market, for example, may be 75 percent; that is, the four largest banks hold 75 percent of the total bank deposits in this market."

Although other factors are analyzed in evaluating the competitive effects of mergers and acquisitions, concentration ratios continue to be the main factors in such analysis. ${ }^{10}$ The important issue is that the calculation of concentration ratios using commercial bank organization deposit data alone accepts the Court's

BFor a discussion of concentration measures used in analysis of banking markets, see "Measures of Banking Structure and Competition," Federal Reserve Bulletin (September 1965), pp. $1212-22$.

"See the appendix for a discussion of how the relevant geographic market is defined.

torhis point is highlighted by the merger guidelines published by the Justice Department in 1968 which are frequently cited in bank merget and acquisition analysis. These guidelines indicate that the department will challenge a horzontal merger between firms in a concentrated industry (i.e. one with a fourfirm concentration ratio greater than $75 \%$ ) wher the following market shares are involved:

\begin{tabular}{|c|c|}
\hline $\begin{array}{c}\text { Acquiring } \\
\text { Firm }\end{array}$ & $\begin{array}{l}\text { Acquired } \\
\text { Finm }\end{array}$ \\
\hline $4 \%$ & $4 \%$ or more \\
\hline $10 \%$ & $2 \%$ or more \\
\hline $15 \%$ & $1 \%$ or more \\
\hline
\end{tabular}

In nonconcentrated markets (i.e. ones with four-firm concentration ratios less than $75 \%$ ) the Justice Department challenges mergers with the following shares:

\begin{tabular}{cc}
$\begin{array}{c}\text { Acguiring } \\
\text { Firm }\end{array}$ & $\begin{array}{c}\text { Acquired } \\
\text { Firm }\end{array}$ \\
\cline { 2 - 2 } $5 \%$ & $5 \%$ \\
$10 \%$ & $4 \%$ \\
$15 \%$ & $3 \%$ \\
$20 \%$ & $2 \%$ \\
$25 \%$ & $1 \%$
\end{tabular}

See Merger Guidelines, U.S. Department of Justice, May 30, 1968. line of commerce definition and assumes that the aggregate of the many products and services supplied by banks represents a meaningful product line for analysis of market competition. ${ }^{11}$

\section{Economic Analysis of Line of Commerce Definition}

The definition adopted by the Court in 1963 was based on a particular view of the market for bank services: namely, that many bank products are demanded jointly. In other words, it is possible to identify "clusters" or "bundles" of services demanded by customers for which banks compete. ${ }^{12}$ Such demand may result because of transportation costs and transaction costs (including the cost of obtaining information) which makes it costly or impractical for customers to deal with more than one institution.

Banks, however, compete in many different product markets and in different geographic market areas. Commercial banks participate principally in markets for financial assets. Banks demand customer deposits which they invest in a variety of earning assets. Cus tomers using demand accounts are, in turn, supplied a transaction service. Customers holding time deposits are provided an intermediation service - funds are invested in interest-earning assets. Banks also supply various types of credit, trust services, safe deposit services, correspondent services, etc. Each of these activities can be identified as an individual "output" of a bank. One can argue that each "output" is sold in

\footnotetext{
11The use of such concentration ratios is not necessarily ad hoc. Their use has both theoretical and empirical support in the literature. Nevertheless, it is reasonable to conclude that the use of such ratios, essentially a result of data scarcity, has unfortunately guided research efforts as well, For a summary of the empirical evidence for banking, see Stephen A. Rhoades, Structure and Performance Studies in Banking; A Summarty and Evaluation, Staff Economic Studies 92 (Board of Govemors of the Federal Reserve System, 1977) and George J. Benston, "The Optimal Banking Struchire: Theory and Evidence," Journal of Bank Research (Winter 1973), pp. 220-37. For a criticism of such "condenct/structure/performance" studies, see Yale Brozen, "Concentration and Profits: Does Concentration Matter?" The Antitrust Bulletin (Summer 1974), pp. 381-99. See also Harold Demsetz, "Industry Structure, Market Rtvalry, and Public Policy," Journal of Law and Economics (April 1973), pp. 1-9.

${ }^{12}$ An alternative argument holds that banks have offered diverse services in the past because they have been prohib ited from paying interest on demand deposits since 1933. Customers holding large demand deposit balances receive "implicit interest" in the form of other services offered below cost to depositors. In other words, competition resulted in institutions, faced with prohibition on direct payment of interest, offering implicit interest in the form of services, such as low or zero service charges, drive-in factlities, branches, and occasionally gifts (porcelain china, silverware and calculators, for example).
} 
a distinct market defined in terms of specific groups of buyers (for example, by location of customer, or maturity and denomination of the particular loan). Therefore, choosing the appropriate measure of bank "output" is a difficult task. ${ }^{13}$

The above reasoning suggests that the usefulness of the line of commerce definition adopted in the Philadelphia case should be determined on empirical grounds. Although the "department store" or "cluster of service" approach may be valid in some instances, the concept is completely irrelevant for many readily identifable bank "products." For example, an individual seeking a mortgage loan will choose an institution primarily on the basis of the price of the loan (the interest rate); the package of other services offered by competing institutions is not pertinent in this decision.

Measuring the extent of competition between different types of institutions in a product line must be based upon the degree of substitution between products of these institutions. In economic terms, the important issue is the magnitude of the "cross-elasticity" of demand between individual products offered by financial institutions. ${ }^{14}$ The higher the cross elasticity between the products of banks and thrifts, the greater the substitution and the stronger the argument for including the outputs of these institutions in the same industry or the same product line. The cluster approach used by the Supreme Court assumes that the degree of substitution between lines of commerce (thrift output and bank output) is "small," For example, if institution A (say, a thrift) increases the (explicit or implicit) interest rate on savings deposits while institution $B$ (a bank) keeps its rates unchanged, the volume of business transferred by local customers from bank B to thrift A rises with the magnitude of the cross-elasticity of supply. The other

${ }^{13}$ Researchers' views have varied considerably in their theoretical definitions of the appropriate banking output measure. See Stuart I. Greenbaum, "Competition and Efficiency in the Banking System - Empirical Research and Its Policy Implications, The Joumal of Political Economy (Supplement: August 1967), pp. 461-79, and Michael A. Klein, "A Theory of The Banking Firm," Journal of Money, Credit, and Banking (May 1971), pp. 205-18.

14The "cross-elasticity" of demand is defined as a measare of the relationship between the demand for one firm's ontput when the price of another firm's output changes (when all other things remain the same). The cross-elasticity between goods 1 and 2 is given by the equation

$e=\frac{\% \text { change in quantity of good } 1 \text { demanded }}{\% \text { change in price of good } 2}$

If $e$ is less than zero, the outputs are normally considered "complements." If e is greater than zero they are considered substitutes. The degree of substitution can be gauged by the magnitude of this coefficient: higher positive cross-elasticity coefficients correspond to greater degrees of substitution. services offered by bank B (for example, checking services), however, may preclude a significant transfer of business between institutions. Since both thrifts and banks can now offer transaction accounts, the degree of substitution between their respective outputs will increase. ${ }^{15}$

Bank regulatory agencies have emphasized the "locally limited" customer in analysis of bank mergers and acquisitions. As such, regulators have tended to stress the services provided to individuals and small business customers. Since most large commercial and industrial customers have access to national and regional markets, competition for these accounts is intense. Empirical estimates of the relevant crosselasticities for retail and small business customers in local banking markets, however, are difficult to obtain. Regulatory ceilings on interest rates interfere with obtaining good estimates of these magnitudes. As previously mentioned, competitive forces have resulted in institutions competing by means other than the payment of explicit rates of interest. Institutions located in different market environments offer differentiated clusters of outputs. Differing degrees of branching restrictions across governmental jurisdictions, for example, may affect the form of implicit interest paid to consumers.

Even before the MCA, other structural changes since the last Supreme Court ruling on a merger case (1974) had cast doubt on the validity of the banking regulatory agencies' approach to competition. The asset and deposit liability growth of thrifts has outpaced that of banks over most of the periods from 1960-79 (tables 2 and 3). It is unlikely that the previous degree of substitution between the outputs of banks and thrifts has remained constant since the Philadelphia definition in 1963. Retail customers in local banking markets have reacted to significant financial developments in the $1970 \mathrm{~s}$. Inflation, interest rate ceilings, and new instruments such as money market certificates, money market funds, ATS accounts and telephone transfer accounts, have all contributed to an increased degree of substitution between services offered by banks and non-bank institutions. The nationwide legalization of thrift transaction accounts further weakens the argument that banks have a clear advantage in attracting customers.

\footnotetext{
${ }^{15}$ Accumulated evidence prior to the MCA supports the view that customers already treat time and savings accounts of hanks and thrifts as strbstitutes. For a review of the empirical evidence before 1970 , see Gary G. Gilbert and Neil $B$. Murphy, "Competition Between Thrift Irstitutions and Commercial Banks: An Examination of the Evidence," Joumal of Bank Research (Summer 1971), pp. 8-18.
} 
Table 2

Distribution of Assets - Commercial Banks and Thrifts (billions of dollars)

\begin{tabular}{lllllll} 
& & \\
\hline
\end{tabular}

COMMERCALL BANKS Gnsured only)

Busmess oans

Mortgages

consuner loans

U.S. hreasury and agenoy sacuritles

State and local seculties

oher assets

TOTAL

\begin{tabular}{|c|c|c|c|c|c|c|c|c|}
\hline & $\$ 712$ & $\$ 1122$ & $\$ 174.3$ & & & $95 \%$ & $\begin{array}{r}9.2 \% \\
13,0\end{array}$ & $101 \%$ \\
\hline 28,7 & 49.4 & 791 & 1346 & 2432 & 8 & 77 & 9.9 & 151 \\
\hline 26.4 & 45.5 & 660 & $106: 0$ & & & & & \\
\hline
\end{tabular}

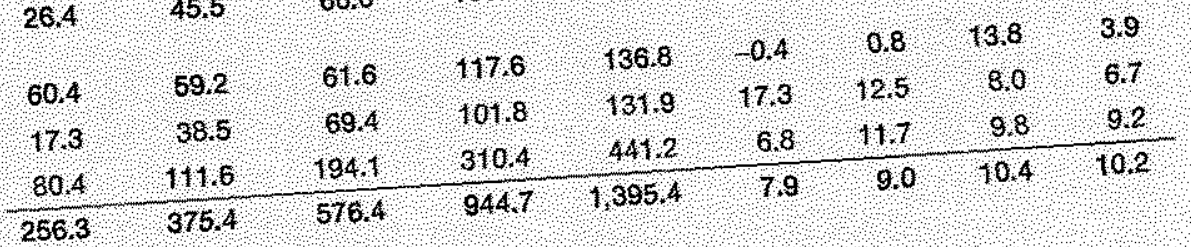

SAVINGS \& LOAN ASSOCIATIONS

Mortgages

Investment securties

other assets

TOTAL

MUTUALSAVNGS BANKS

Mortgages

U,S. government seeurities

State and local securties

Conporate and other securities

other assets

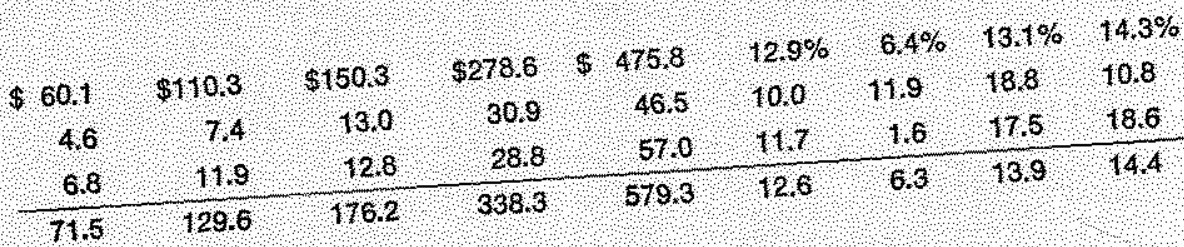

TOTAL

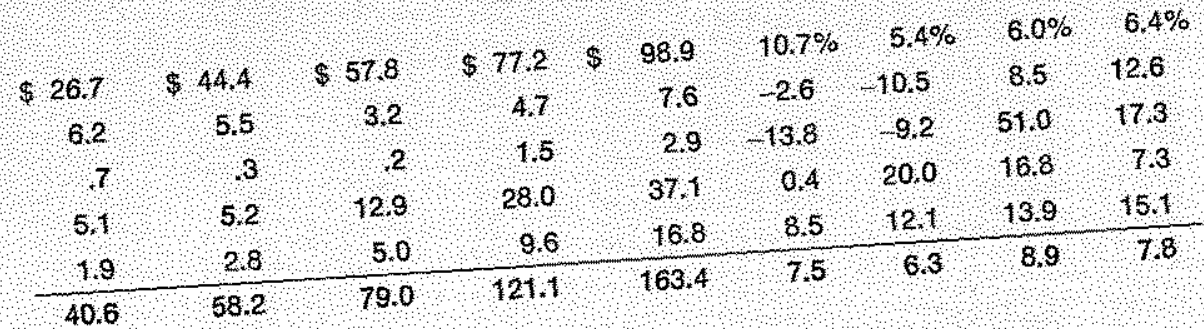

CREDIT UNIONS

Loane outstanding

other assets

TOTAL

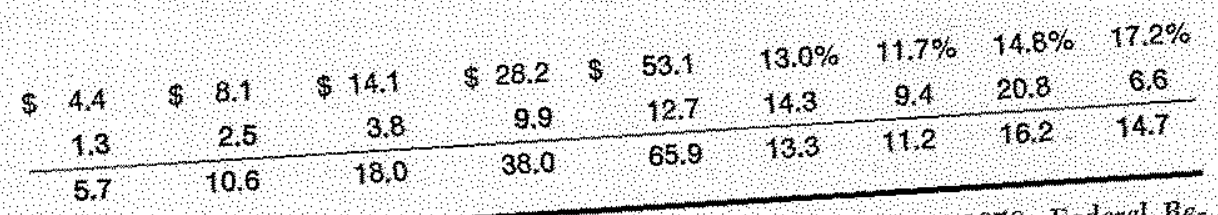
SOUnCHs Bankitig and Manetary 5 tatistios, 19411970,

The presumed "settled consumer preference" for banks over competing institutions has become less and less evident. ${ }^{10}$ First, S\&Ls have unique advantages over banks. They enjoy statewide branching privileges,

16The "settled consumer preference" notion adopted by the thenomic theory. Nicroeconomic theory Court conthicts with econers cheice beiween the ontputs of explans that a consumer the relative prices of those outmany banks is based on "settled" or stable, in that they are puts. All preferences are settled of price. Such stable preterconsidered to be independent of pre. Sues in response to ences, however, do prices. for example, in some states that limit branching for: banks second, new technology continues to alter the tritional methods of marketing financial services. Electronic banking is the most obvious example of the declining importance of locational convenience in banking - i.e., one-stop banking. Automated teller machines, automatic payroll check deposit, banking by mail and point-of-sale terminals expand the geographic scope of competition among depositary locally tutions for what was once considered the locally limited customer. 


\section{Table 3}

\section{Composition of Deposits (billions of dollars)}

\begin{tabular}{|c|c|c|c|c|c|c|c|c|c|}
\hline & \multicolumn{5}{|c|}{ End of Period } & \multicolumn{4}{|c|}{ Annual Growth hates } \\
\hline & 1960 & 1965 & 1970 & 1975 & 1979 & $\begin{array}{l}1960 . \\
1965\end{array}$ & 1965 & 1970 & 1975 \\
\hline \multicolumn{10}{|l|}{ COMMERCIALBANKS } \\
\hline Demand & $\$ 1557$ & $\$ 180,8$ & $\$ 2472$ & $\$ 3198$ & 8429.5 & $3.4 \%$ & $6,1 \%$ & $5,3 \%$ & $77 \%$ \\
\hline Tlme and savings & 73,3 & 1477 & 235.3 & 455.5 & 656.5 & 150 & 98 & 141 & 9.6 \\
\hline ßTOTAL & 229.0 & 331.5 & 4825 & 7752 & 1,0660 & 77 & 78 & 99 & 8.8 \\
\hline \multicolumn{10}{|l|}{$\begin{array}{l}\text { SAVINGS AND LOAN } \\
\text { ASSOCIATIONS }\end{array}$} \\
\hline$\$$ Savings capital & $\$ 621$ & $\$ 110.4$ & $\$ 146.4$ & $\$ 2857$ & $\$ 470.2$ & $122 \%$ & $58 \%$ & $143 \%$ & $13.3 \%$ \\
\hline \multicolumn{10}{|c|}{ MUTUAL SAVNGS BANKS } \\
\hline ' Tine and savings & $\$ 36,1$ & $\$ 521$ & $\$ 712$ & 81093 & $\$ 144.1$ & $76 \%$ & $64 \%$ & $90 \%$ & $72 \%$ \\
\hline other & 1 & ?ै। & 4 & 186 & 1,9 & 5,1 & 488 & 66 & 351 \\
\hline TOTAL & 36.3 & 524 & 716 & 109.9 & 146.0 & 76 & 6.4 & $8 \%$ & 74 \\
\hline \multicolumn{10}{|l|}{ OREDIT UNONS } \\
\hline Member savings & 850 & 92 & 816.5 & $\$ 330$ & 856.2 & $13 \%$ & $10.9 \%$ & $163 \%$ & $14.2 \%$ \\
\hline
\end{tabular}

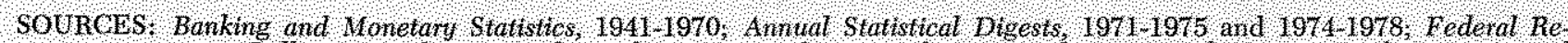
serve Bulletin, March 1980 and Octobet 1980 , and Nationat Foct Book of Wutud Satings Banking, 1976 ard 1980

\section{Legal Issues}

The Supreme Court case that most recently addressed the relevance of thrifts in competitive analysis was the Connecticut National Bank case in 1974.17 A lower court had found that savings banks were "fierce competitors" of banks in certain markets. The Supreme Court, however, reaffirmed the line of commerce definition adopted in the Philadelphia case, maintaining that commercial banks offer a unique cluster of services that distinguish them from other institutions. The Court in particular emphasized that there was a lack of significant competition between banks and mutual savings banks for commercial accounts.

There was, however, an indication that the Court realized that the Philadelphia definition's usefulness was declining. For example, in the Connecticut case the Court stated:

At some stage in the development of savings banks it will be unrealistic to distinguish them from commercial banks for purposes of the Clayton Act. In

17 United States v. Connecticut National Bank, 418 U.S. 656 (1974).
Connecticut, that point may well be reached when and if savings banks become significant participants in the marketing of bank services to commercial enterprises. But, in adherence to the tests set forth in our earlier bank merger cases, ... such a point has not yet been reached. ${ }^{18}$

The Court's emphasis on competition for commercial business has led some analysts to speculate that, even with the passage of the MCA, thrifts will still be excluded from the Federal Reserve's competitive analysis of mergers and acquisitions. Indeed, the quantitative impact of the new law is greater with respect to the array of services offered to retail customers. All depository institutions in the nation may offer NOW accounts, but not to commercial and business enterprises. ${ }^{19}$ Mutual savings banks are now permitted to

1slbid.

19 NOW accounts are to be made available only to an individual or to an organization that is "primarily for religtous, philanthropic charitable, edicational, or other similar purposes and which is not for profit." These depositors have been defined by the Federal Reserve Board to include individuals, sole proprietors, husbands and wives operating unincorporated businesses, local housing authorities, residential tenant security deposits, independent school districts and redevelopment anthorities. 
extend business loans (up to 5 percent of total assets) to firms within 75 miles of their main office, but since most mutual savings banks are located in the East, their competitive impact will be limited to eastern markets. Likewise, the commercial lending authority granted to mutual savings banks applies only to savings banks with federal charters. In addition, expanded services to corporations would remain generally unavailable from S\&Ls. The MCA, however, permits Federal S\&Ls to invest in commercial paper and corporate debt securities (up to 20 percent of assets).

Whether these specific changes will be sufficient to alter the line of commerce definition in court cases is an unsettled issue. Although the competitive impact of the MCA on competition for commercial customers may not be viewed as substantial in quantitative terms, any marginal increases must be considered significant since these new powers allow additional entrants into markets for these services.

\section{SOVE ATERNATIVES}

Many analysts believe that a different approach to the analysis of competition among depository institutions is called for, ${ }^{20}$ To a limited degree, banking authorities have already begun to introduce the influence of thrifts into their analysis. ${ }^{21}$ The question still remains, however, how the impact of increasing thrift competition should be weighted in the analysis. In other words, how would the line of commerce be "unbundled?" Should commercial banks, mutual savings banks and S\&Ls together encompass a line of commerce, or should individual product markets of these institutions be analyzed? Several options are avaitable.

\footnotetext{
20See, for example, Henry C. Wallich and Walter A. Varvel, "Evolution in Banking Competition," The Bankers Magazine (November/December 1980), pp. 26-34, and Commercial Banking as a Line of Commerce: An Examination of $T$ ts Economic and Market Validity in Commercial Bank Anti trust Law, prepared by Colembe Associates Eric. for the Association of Bank Holding Companies (Decenber 1980).

231For recent Federal Reserve actions see (1) approval for the Therger of The Bank of New York with Empire National Bank, Federal Reserve Bulletin (September 1980), pp. 807$09 ;(2)$ denial for Republic of Texas Corporation to acquire Citizens National Bank of Waco, Federal Reserve Bulletin (September 1980), pp. 787-89; (3) approval for Key Banks, Inc., to acquire the National Bank of Northem New York, Federal Reserve Bulletin (September 1980), pp. 781-89; (4) derial tor Texas Commerce Bancshares, Tnc to acouire The First National Bank of Port Neches, Federal Reserve Bulletin (July 1980), pp. 584-85; (5) denia for thepublic of Texas Comporation to merge with Fort Sam Houstor Bankshares, Inc. Federal Reserve Bulletin (fuly 1980), pp. 580-82, (6) approval for Fidelity Union Bancorporation to acquire Garden Sate National Bank, Federal Reserve Bulleth (July 1980), po. 576-79; (7) denial for United Bank Corporation of New rork to acquire The Schenectady Trust Company. Federal heserve Bulleth (January 1980), pp. 61.64.
}

\section{Add Thrifts to Line of Commerce Framework}

One alternative is simply to include thrift institutions as direct competitors of banks; in other words, treat thrifts as commercial banks for purposes of a line of commerce definition. Concentration ratios would continue to be the most likely candidates as the key proxies for measuring competition under such an approach. Including thrifts into the analysis would liberalize merger and acquisition policy to some degree. Since concentration ratios would be diluted by deposits or assets of thrifts, the number of possible bank mergers meeting the Justice Department's current merger and acquisition "standards" would be increased. ${ }^{22}$

Unfortunately, this approach suffers from the same Haws that exist with the general use of "commercial banking" as a line of commerce definition. Because significant differences exist in the asset and liability powers between banks and thrifts, competition varies across relevant product lines. Likewise, the varying forms of financial structure observed among geographic areas of the country (location of mutual savings banks in the East and different thrift and bank branching laws across states, for instance) make such concentration ratios difficult to apply consistently.

Maintaining the line of commerce framework by including thrifts but continuing to rely on aggregated market share statistics also suffers from major economic flaws. As argued above, the relevant crosselasticities among products of banks and thrifts have been altered by changes in technology and a great number of financial innovations in recent years. Likewise, as regulations on interest rate ceilings are removed over the next six years, financial institutions will undoubtedly "unbundle" their own services. Competition among institutions will result in independently priced services and these prices will more closely approximate the marginal costs of their provision.

\section{Maintain Current Approach With "Stubjective" Addition of Thrifts}

Another alternative is to maintain the current approach of including only banks in concentration analysis, except in cases where thrifts are seen as "signifcant competitors." In such cases, thrifts would be used

22 For an evaltation of the impact of including thrift deposits in makket concentration rateo calculations for banking markets in New York and New Jersey, see Roger $\mathbf{E}$. Alcaly and Richard W. Nelson, "Will lneluding Thrifts in the Banking Market Affect Mergers," The Banking Law Journal (April 1980 ), pp. 346-51. 
in calculating market share data. In essence, this is the approach that the banking regulatory authorities are now using and, given the uncertainties of the MCA's impact, is the likely route they will follow during a transition period. This methodology provides enough flexibility to accommodate regional differences in market structure, but is not likely to be legally satisfying given its subjective framework. In addition, it suffers from the same problems as the current line of commerce definition of lumping together the many outputs of banks and thrifts into one aggregate measure.

\section{Un Wunde Fmancial Institution Products}

A third alternative, more consistent with economic theory, is to disaggregate the traditional line of commerce (defined as commercial banking) into specific subcategories. Though this strategy would more accurately reflect the actual competitive situation, it would increase the difficulty of assessing the impact on "overall" competition. Regulators would first be faced with the problem of assigning weights to the competitive effects of a merger or acquisition across product lines. Since institutions are multi-product producers, it is possible that competition among firms may be lessened for some outputs but not for others. For example, two local banks proposing to merge might produce a monopoly on local trust services but still generate vigorous competition with many other financial institutions for checking and savings deposits. Depending on the relative weights assigned to the competitive effects across product lines (which would continue to be measured by concentration ratios), the disaggregated product approach might result in a more restrictive stance against mergers and acquisitions.

A second limitation to the disaggregation approach is the lack of detailed statistios measuring some prod- uct lines. Each product line might correspond to a different geographic market. Correspondent banking services, for example, would have to be analyzed in terms of larger geographic regions (e.g., a state), whereas small business loans would be analyzed within a more localized market. One would have to identify both customers of such product lines and the financial institutions offering close substitutes for this approach. Practical data problems would therefore limit the degree of disaggregation possible.

\section{CONCLUSTON}

Although Supreme Court cases to date have consistently upheld "commercial banking" as a distinct line of commerce definition in bank merger cases, the foundation of the Court's reasoning has eroded since 1963. Significant market changes since the last Supreme Court case (1974) cast doubt on the practice of evaluating mergers and acquisitions as narrowly as the traditional analysis requires.

With the passage of the Monetary Control Act, there is greater reason to depart from the established tradition of treating commercial banking as an exclusive line of commerce in antitrust analysis. A more broadly defined line of commerce would increase the number of mergers and acquisition proposals meeting antitrust standards. On the other hand, a disaggregated approach to analyzing the product lines of banks and thrifts would more accurately scrutinize proposals for actual anticompetitive effects. Such changes in product and geographic market definitions will have important implications for the future structure and competitive performance of the financial industry. Although the proper analytic approach is still evolving, increased thrift competition will certainly play a more significant role in the evaluation of future bank mergers and BHC acquisition proposals.

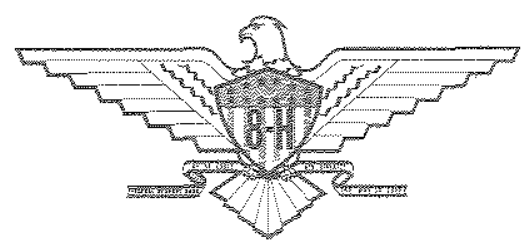




\section{Appendix Defining Banking Markets}

The most crucial element of competitive analysis in many bank merger and acquisition cases is the definition of the relevant local banking market. In many proposals analyzed by the Federal Reserve, the only dispute (over which approval or denial of an application depends) is over the appropriate market definition. Given the tendency of the courts in recent years to rely on simple market share tests, it is important to understand the logic and reasoning behind the delineation of banking markets.

There are both conceptual and empirical problems in defining banking markets. The conceptual problems deal with describing the relationship between "sellers" and "buyers," so that an area can be defined as a market. The most basic and widely accepted concept for analyzing markets is "cross-elasticity of demand." The crossprice-elasticity is a measure which summarizes the relationship between the change in price of any one firm's output and the amount of business done by others (see footnote 14 in text). If an increase (decrease) in the price of one firm's service results in a significant increase (decrease) in the sales of another, the two may be considered to be subject to the same market forces - and are in the same market. Economic theory does not tell us, however, what magnitude of the cross-elasticity should be used for such determinations. It does tell us that if competition exists, output prices of these firms tend to equalize to prices equivalent to the marginal cost of providing these services.

Implementing this conceptual framework in actual casework is not easily achieved. Since price data to measure cross-elasticities are difficult to obtain, a number of other proxies are used in defining a market. Most of these indirect measures of cross-elasticity center around judgments about the "reasonable interchangeability" of the products of firms. The "products," of course, have been defined as the general category of banking services (total deposits being used as a proxy for such output) to conform to the line of commerce definition adopted by the courts.

Although there is no uniformly accepted method of defining banking markets, the following items are important factors in the process of defining markets.

A. Structural information - the size and location of competing institutions and branches, other statutes which restrict actual or potential entry (restrictive chartering practices and branching laws, for example).

B. Distance factors and commuting patterns - the distance between relevant competing institutions, traffic flows, the quality of roads and other natural boundaries which affect access to competing institutions.

C. Political boundaries - county and state boundaries (banking laws which restrict branching within such boundaries adds some weight to using these definitions).

D. Geographic distribution of advertising - radio, television and newspapers.

A useful proxy for interaction of suppliers of banking services and customers is primary service area (PSA) data. The PSA is normally defined as that geographic area contiguous to an office from which 80 percent of the dollar amount of that office's deposits is derived. Applicants are frequently requested to submit comparable data for other services (e.g., demand deposits, savings deposits, loans, etc.).

Confusion reigns among bankers about the difference between PSAs and markets as economists define them. The lack of overlapping service areas between banks does not necessarily mean that banks are located in distinct market areas. The two are not equivalent concepts, All of the factors mentioned above may make the market substantially larger than a bank's PSA. In other words, two banks, competing in the same market, need not have common customers or overlapping PSAs.

For those wishing to review the literature on the analytics of defining banking markets, the following sources are suggested:

David D. Whitehead, "Relevant Geographic Banking Markets: How Should They Be Defined?" Federal Reserve Bank of Atlanta Economic Review (January/ February 1980), pp. 20-28.

Paul R. Schweitzer, "Definition of Banking Markets," Banking Law Joumal (September 1973), pp. 745-62.

Ira Horowitz, "On Defining the Geographic Markets in Section 7 Cases," Federal Reserve Bank of Chicago Proceedings of a Conference on Bank Structure and Competition (1977), pp. 169-82.

Charles D. Salley, "Uniform Price and Banking Market Delineation," Federal Reserve Bank of Atlanta Monthly Review (June 1975), pp. 86-93.

Douglas V. Austin, "The Line of Commerce and the Relevant Geographic Market in Banking: What Fifteen Years of Trials and Tribulations Has Taught Us and Not Taught Us About The Measure of Banking Structure," Federal Reserve Bank of Chicago Proceedings of a Conference on Bank Strticture and Competition (1977), pp. 185-209.

Steven A. Mathis, Duane G. Harris and Michael Boehlje, "An Approach to the Delineation of Rural Banking Markets," American Journal of Agricultural Economics (November 1978), pp. 601-08. 